\title{
ANALISIS MOTIVASI, TIPOLOGI, DAN PERILAKU WISATAWAN YANG BERKUNJUNG KE PURA TIRTA EMPUL
}

\author{
I Nyoman Agus Wira Prabawa \\ Universitas Udayana \\ Email: wirasantika88@gmail.com \\ I Nyoman Sunarta \\ Universitas Udayana \\ Email: cairns54@yahoo.com \\ I Gusti Ayu Oka Suryawardani \\ Universitas Udayana \\ Email: gungdani@gmail.com
}

\begin{abstract}
Pura Tirta Empul is a tourist attraction located in Gianyar regency of Bali. As a tourist attraction that provides nature and culture, Tirta Empul Temple is visited by many tourists, especially foreign tourists. Tirta Empul Temple becomes the locus in this research. The purposes of this study are to determine the motivation of tourists, characteristics / typology of tourists, and the behavior of tourists who visit Tirta Empul Temple. The theory used in this research is motivation theory that is divided into two factors, namely pull factor and push factor. While the concepts used are concept of cultural tourism, concept of motivation, concept of tourist typology, and concept of tourist's behavior. The results showed that the main motivation of tourists in visiting Tirta Empul Temple is dominated by two factors, namely natural and cultural attractions and the desire for relaxation. While the typology of tourists, tourists who visit Tirta Empul Temple mostly are sightseeing tourists. As for the tourist behavior especially about the tourst's activity is divided into two, namely activities related to religious and recreational activities. The number of tourist's expenditure is not too much and the majority of tourist said their intent not to return.
\end{abstract}

Keywords: motivation, typology, tourist behavior, tirta, empul

\section{Pendahuluan}

Pariwisata merupakan fenomena dunia yang mempunyai ruang lingkup luas. Secara sederhana, pariwisata dicirikan dengan adanya wisatawan yang berkunjung ke suatu tempat dengan tujuan tertentu. Lazimnya, tujuan tersebut adalah untuk 
mencari dan mengeksplorasi hal-hal baru. Salah satu diantaranya adalah yang terkait motif budaya, yakni keinginan untuk mengetahui dan mempelajari "budaya luar".

Pura Tirta Empul adalah salah satu manifestasi budaya di Bali. Fungsi utamanya adalah sebagai tempat pemujaan, yang kemudian juga menjadi daya tarik wisata. Dalam beberapa wacana pariwisata, Pura Tirta Empul sering diistilahkan "The Holy Spring Water Temple". Keistimewaan Pura Tirta Empul adalah karena adanya mitos bahwa di Pura Tirta Empul terdapat sumber air yang memiliki beragam khasiat. Keberadaan mitos tersebut berdampak terhadap rasa ingin tahu wisatawan yang lebih dalam untuk mencoba kebenaran mitos tersebut. Mitos, yang tidak lain adalah sesuatu yang belum jelas kebenarannya, dalam pariwisata justru sering sekali menjadi alasan dan pembenaran atas perjalanan wisata yang dilakukan. Hal tersebut dapat dilihat di Pura Tirta Empul, hampir semua wisatawan yang datang, khususnya non-Bali, turun dan terlibat secara langsung melakukan aktivitas penyucian diri dengan menggunakan air Pura Tirta Empul.

Tidak hanya terlibat dalam aktivitas yang terkait keagamaan, wisatawan khususnya wisatawan mancanegara juga melakukan kegiatan yang terkait rekreasi seperti berjalan-jalan di areal Pura, berfoto-foto, dan berinteraksi dengan rekanrekannya. Wisatawan sangat menikmati panorama alam dan wujud-wujud budaya yang ada di Pura Tirta Empul. Di sisi lain, aktivitas-aktivitas yang diakukan wisatawan tesebut menimbulkan semacam sentimen negatif dari masyarakat lokal. Keberadaan wisatawan dianggap mengganggu bahkan merusak konsentrasi masyarakat lokal ketika melakukan pemujaan dan aktivitas agama lainnya. Hal ini didukung oleh hasil studi Setiawan (2011) tetang Pura Tirta Empul yang menemukan bahwa penggunaan Pura Tirta Empul sebagai daya tarik wisata cenderung negatif yakni komodifikasi Pura menghasilkan komersialisasi Pura, memudarnya identitas, dan pencemaran Pura. Komodifikasi yang terjadi dapat dilihat sebagai sebuah proses menjadikan kebudayaan sebagai komoditi, dengan tujuan untuk memenuhi kebutuhan pasar (Suteja, Ardika, dan Pujaastawa 2018)

317 JUMPA Volume 05, Nomor 02, Januari 2019 
Pariwisata Bali dengan idiologinya pariwisata budaya memang selalu diuji. Memahami pariwisata budaya sebagai sebuah konsep, ketika konsep tersebut diaktifkan, muncul dua paradigma sekaligus, pertama, paradigma pelestarian budaya, dan yang kedua adalah paradigma pemanfaatan modal budaya seoptimal mungkin dalam pencapaian modal ekonomi. Oleh karena itu, utilisasi warisan budaya menjadi daya tarik wisata harus dilakukan secara terarah, optimal, dan bertanggungjawab. Seperti yang diungkapkan oleh Palimbunga (2018), bahwa untuk mengembangkan kegiatan pariwisata maka diperlukan pengelolaan yang baik dengan didukung oleh sumber daya manusia yang ahli, berkomitmen, seta berpengalaman dalam bidang pariwisata. Studi ini memfokuskan wisatawan sebagai objek kajian, dengan orientasi penyempurnaan pemahaman yang konstruktif tentang pengoptimalan daya tarik wisata yang statusnya adalah warisan budaya. Studi ini diformat melalui tiga rumusan permasalahan, yakni motivasi wisatawan, tipologi wisatawan, dan perilaku wisatawan.

\section{Landasan Teori dan Metode}

Studi ini menggunakan teori motivasi menurut McIntosh (dalam Pitana, 2005), yang kemudian motivasi ditinjau dari dua faktor yaitu faktor penarik dan faktor pendorong. Motivasi dari faktor penarik dikemukakan oleh Uysal dan Hagan (dalam Zeng, 2015), yang meliputi: natural and historic attraction, people, recreation facilities, dan marketed image of the destination. Selanjutnya, motivasi dari faktor pendorong dikemukakan oleh Yoon dan Uysal (dalam Woodside, 2008), terdiri atas: rest and relaxation, desire to escapei, health, social interaction, dan adventure. Studi ini menggunakan metode pendekatan analisis deskriptif kualitatif yang didukung dengan pendekatan kuantitatif. Data-data dalam studi ini dikumpulkan dengan observasi, penyebaran kuesioner, interview, dan studi kepustakaan. Teknik analisis data menggunakan deskriptif kualitatif dan teknik analisis skala likert. 


\section{Pembahasan}

Motivasi wisatawan ditinjau dari faktor penariknya, menunjukkan motivasi yang beragam. Motivasi-motivasi tersebut dapat dilihat pada Tabel 1.

Tabel 1. Motivasi Wisatawan

\begin{tabular}{|c|c|c|c|c|c|c|c|c|c|c|c|c|}
\hline \multirow[t]{2}{*}{$\begin{array}{l}\text { Faktor } \\
\text { Penarik }\end{array}$} & \multicolumn{2}{|c|}{$\begin{array}{l}\text { Sangat } \\
\text { Setuju }\end{array}$} & \multicolumn{2}{|c|}{ Setuju } & \multicolumn{2}{|c|}{ Netral } & \multicolumn{2}{|c|}{$\begin{array}{l}\text { Tidak } \\
\text { Setuju }\end{array}$} & \multicolumn{2}{|c|}{$\begin{array}{l}\text { Sangat } \\
\text { Tidak } \\
\text { Setuju }\end{array}$} & \multirow[t]{2}{*}{$\begin{array}{l}\text { Total } \\
\text { Skor }\end{array}$} & \multirow[t]{2}{*}{ Nilai } \\
\hline & $\begin{array}{l}\text { Jml } \\
\text { (org) }\end{array}$ & Skor & $\begin{array}{l}\text { Jml } \\
\text { (org) }\end{array}$ & Skor & $\begin{array}{l}\text { Jml } \\
\text { (org) }\end{array}$ & Skor & $\begin{array}{l}\text { Jml } \\
\text { (org) }\end{array}$ & $\begin{array}{l}\text { Sko } \\
\text { r }\end{array}$ & $\begin{array}{l}\text { Jml } \\
\text { (org) }\end{array}$ & $\begin{array}{l}\text { Sko } \\
\mathrm{r}\end{array}$ & & \\
\hline $\begin{array}{l}\text { Daya tarik } \\
\text { wisata } \\
\text { alam dan } \\
\text { budaya }\end{array}$ & 72 & 360 & 21 & 84 & 7 & 21 & - & - & - & - & $\begin{array}{l}465 / 100 \\
=4.65\end{array}$ & $\begin{array}{l}\text { Sang } \\
\text { at } \\
\text { Setuj } \\
\mathrm{u}\end{array}$ \\
\hline $\begin{array}{l}\text { Fasilitas } \\
\text { rekreasi }\end{array}$ & - & - & 2 & 8 & 51 & 153 & 35 & 70 & 12 & 12 & $\begin{array}{l}243 / 100 \\
=2.43\end{array}$ & $\begin{array}{l}\text { Tida } \\
\mathrm{k} \\
\text { Setuj } \\
\text { u }\end{array}$ \\
\hline $\begin{array}{l}\text { Citra } \\
\text { destinasi }\end{array}$ & 14 & 70 & 47 & 188 & 18 & 54 & 21 & 42 & - & - & $\begin{array}{l}354 / 100 \\
=3.54\end{array}$ & $\begin{array}{l}\text { Setuj } \\
\mathrm{u}\end{array}$ \\
\hline $\begin{array}{l}\text { Masyaraka } \\
\text { t lokal }\end{array}$ & 15 & 75 & 20 & 8- & 45 & 135 & 14 & 28 & 6 & 6 & $\begin{array}{l}324 / 100 \\
=3.24\end{array}$ & $\begin{array}{l}\text { Netr } \\
\text { al }\end{array}$ \\
\hline
\end{tabular}

Sumber: Hasil Penelitian (2018)

Berdasarkan Tabel 1, indikator daya tarik wisata alam dan budaya mendapatkan penilaian tertinggi dari wisatawan dengan skor 4.65 dengan penilaian sangat setuju. Hal ini menunjukan bahwa sebagian besar wisatawan yang berkunjung ke Pura Tirta Empul adalah wisatawan yang memiliki ketertarikan untuk mengetahui secara langsung daya tarik alam dan budaya yang ada di Pura Tirta Empul. Pura Tirta Empul merupakan salah satu daya tarik wisata yang disukai wisatawan karena pesona alam dan budayanya yang menarik, contohnya suasana alam yang sejuk serta masih asri yang membuat wisatawan nyaman saat berada di 
Pura Tirta Empul. Pada unsur budaya, beberapa aktivitas agama yang dilaksanakan seperti pemujaan dan penyucian diri (purification) di kolam Pura Tirta Empul menjadi daya tarik wisatawan yang kuat.

Indikator selanjutnya yakni citra destinasi yang memperoleh skor 3.54 dengan penilaian setuju dari responden. Citra destinasi merupakan indikator kedua yang mendapatkan penilaian tinggi setelah indikator daya tarik wisata alam dan budaya. Hal ini menunjukkan bahwa beberapa wisatawan yang berkunjung ke Pura Tirta Empul ditarik dengan baiknya citra Pura Tirta Empul itu sendiri. Dalam beberapa wacana pariwisata, Pura Tirta Empul sering diistilahkan The Holy Spring Water Temple. Dengan kata lain, Pura Tirta Empul memiliki citra destinasi yang unik yang mengakibatkan masifnya kunjungan wisatawan ke Pura Tirta Empul. Pura Tirta Empul memiliki citra destinasi yang baik dan unik yang tidak sama dengan citra daya tarik wisata lainnya yaitu The Holy Spring Water Temple. Citra ini tentu bernilai unik khususnya di mata wisatawan mancanegara dan bernilai positif bagi Pura Tirta Empul karena dengan adanya mitos ini membuat wisatawan termotivasi untuk berkunjung dan mencari tahu kebenaran mitos tersebut.

Indikator selanjutnya yaitu masyarakat lokal, dengan skor 3.24 dengan penilaian netral dari responden. Sisi yang dieksplor salah satunya yaitu kehidupan sosial masyarakat lokal di Pura Tirta Empul. Kehidupan masyarakat lokal yang dimaksud adalah kebiasaan sehari-hari yang dilakukan oleh masyarakat Bali khususnya aktivitas-aktivitas yang berhubungan dengan agama dan budaya. Di Pura Tirta Empul, wisatawan dapat menyaksikan kehidupan sosial masyarakat Bali. Aktivitas-sktivitas seperti pemujaan, penyucian diri beserta seluruh simbol-simbol kebudayaan yang ada di Pura Tirta Empul dapat merepresentasikan bagaimana kehidupan masyarakat Bali.

Indikator terakhir yaitu fasilitas rekreasi yang mendapatkan skor 2.43 dengan penilaian tidak setuju dari responden. Hal ini berarti bahwa sebagian besar wisatawan yang berkunjung ke Pura Tirta Empul ini tidak tertarik mengunjungi Pura Tirta Empul karena fasilitas rekreasi yang ada di Pura Tirta Empul, yang 
dikarenakan sebagai daya tarik wisata budaya Pura Tirta Empul tidak memerlukan begitu banyak fasilitas rekreasi lainnya. Fasilitas yang disediakan hanyalah fasilitasfasilitas utama yang dibutuhkan masyarakat lokal yang berkaitan dengan aktivitas keagamaan.

\section{Faktor Pendorong}

Selain adanya faktor penarik, terdapat juga faktor pendorong yang menyebabkan wisatawan melakukan perjalanan wisata. Jika ditinjau dari faktor pendorong, motivasi wisatawan yang berkunjung ke Pura Tirta Empul dapat dilihat secara lebih jelas pada Tabel 2.

Tabel 2. Motivasi Wisatawan

\begin{tabular}{|c|c|c|c|c|c|c|c|c|c|c|c|c|}
\hline \multirow[t]{2}{*}{$\begin{array}{l}\text { Faktor } \\
\text { Pendorong }\end{array}$} & \multicolumn{2}{|c|}{ Sangat Setuju } & \multicolumn{2}{|c|}{ Setuju } & \multicolumn{2}{|c|}{ Netral } & \multicolumn{2}{|c|}{ Tidak Setuju } & \multicolumn{2}{|c|}{$\begin{array}{ll}\text { Sangat } & \text { Tidak } \\
\text { Setuju } & \end{array}$} & \multirow[t]{2}{*}{$\begin{array}{l}\text { Total } \\
\text { Skor }\end{array}$} & \multirow[t]{2}{*}{ Nilai } \\
\hline & $\begin{array}{l}\text { Jml } \\
\text { (org) }\end{array}$ & Skor & $\begin{array}{l}\text { Jml } \\
\text { (org) }\end{array}$ & Skor & $\begin{array}{l}\text { Jml } \\
\text { (org) }\end{array}$ & Skor & $\begin{array}{l}\text { Jml } \\
\text { (org) }\end{array}$ & Skor & $\begin{array}{l}\text { Jml } \\
\text { (org) }\end{array}$ & Skor & & \\
\hline $\begin{array}{ll}\text { Bersantai dan } \\
\text { berelaksasi }\end{array}$ & 59 & 295 & 23 & 92 & 17 & 51 & 1 & 2 & - & - & $\begin{array}{l}440 / 100= \\
4.40\end{array}$ & $\begin{array}{l}\text { Sangat } \\
\text { Setuju }\end{array}$ \\
\hline $\begin{array}{l}\text { Melarikan diri } \\
\text { dari rutinitas } \\
\text { sehari-hari }\end{array}$ & 60 & 300 & 17 & 68 & 21 & 63 & 2 & 4 & - & - & $\begin{array}{l}435 / 100= \\
4.35\end{array}$ & $\begin{array}{l}\text { Sangat } \\
\text { Setuju }\end{array}$ \\
\hline Berpetualang & 14 & 70 & 60 & 240 & 23 & 69 & 3 & 6 & - & - & $\begin{array}{l}385 / 100= \\
3.85\end{array}$ & Setuju \\
\hline Interaksi social & 8 & 40 & 16 & 64 & 63 & 189 & 7 & 14 & 6 & 6 & $\begin{array}{l}313 / 100= \\
3.13\end{array}$ & Netral \\
\hline Kesehatan & 6 & 30 & 36 & 144 & 54 & 162 & 2 & 4 & 2 & 2 & $\begin{array}{l}342 / 100= \\
3.42\end{array}$ & Setuju \\
\hline
\end{tabular}

Sumber: Hasil Penelitian (2018)

Berdasarkan Tabel 2, indikator bersantai dan berelaksasi mendapatkan skor tertinggi yaitu 4.40 dengan penilaian sangat setuju dari responden. Besarnya penilaian wisatawan terhadap indikator keinginan untuk bersantai atau berelaksasi menunjukkan masih kuatnya persepsi wisatawan untuk mencari daya tarik wisata yang dirasa mampu untuk memenuhi kebutuhan tersebut. Di Pura Tirta Empul, wisatawan dapat memenuhi unsur bersantai dan berelaksasi dengan berjalan-jalan, 
swafoto, memberi makan ikan, ataupun berpartisipasi dalam aktivitas-aktivitas yang sifatnya teologis, seperti pemujaan dan penyucian diri.

Indikator kedua yaitu keinginan untuk melepaskan dari rutinitas keseharian mendapatkan skor 4.35 dengan penilaian sangat setuju dari responden. Indikator keinginan untuk melepaskan diri dari rutinitas keseharian hampir sama dengan indikator sebelumnya yaitu indikator bersantai dan berelaksasi, yang dikarenakan sebagian besar wisatawan yang berkunjung ke Pura Tirta Empul adalah wisatawan yang ingin melepaskan dari rutinitas kesaharian sambil bersantai dan berelaksasi di Pura Tirta Empul.

Indikator selanjutnya yaitu berpetualang mendapatkan poin 3.85 dengan penilaian setuju dari responden. Perjalanan wisata memang tidak dapat dilepaskan dari upaya untuk memperoleh pengalaman. Berbagai alasan wisatawan dalam melakukan perjalanan wisata sebenarnya adalah untuk menemukan "dunia baru". Di sisi lain eksistensi daya tarik wisata Pura Tirta Empul membuka peluang sekaligus opsi baru bagi wisatawan yang ingin berpetualang untuk mengetahui sejarah, budaya maupun kehidupan masyarakat Bali, dan Pura Tirta Empul juga merepresentasikan hal tersebut.

Indikator selanjutnya yakni kesehatan yang mendapatkan skor 3.42 dengan penilaian setuju dari responden Hal ini tidak lepas dari keberadaan mitos air Pura Tirta Empul. Kekuatan mitos yang dibalut dengan narasi citra yang unik berhasil menghasilkan pergerakan wisatawan secara nyata. Di Pura Tirta Empul, wisatawan memberikan tanggapan yang baik mengenai indikator kesehatan karena selain sebagai tempat untuk berekreasi di Pura Tirta Empul terdapat sumber air yang di yakini suci oleh masyarakat lokal yang mampu memulihkan penyakit seseorang atau membuat kesehatan seseorang menjadi lebih baik lagi. Oleh karena itu, faktor kesehatan juga dapat menjadi salah satu alasan seseorang dalam berwisata.

Indikator terakhir adalah interaksi sosial yang mendapatkan skor 3.13 dengan penilaian netral dari responden. Ini berarti bahwa wisatawan tidak begitu termotivasi ke Pura untuk melakukan interaksi sosial yang dalam dengan 
masyarakat lokal. Pencapaian angka netral pada indikator interaksi sosial membuka jalan pikiran baru bahwa aspek masyarakat lokal khususnya di Pura Tirta Empul harus lebih dioptimalkan salah satunya dengan peningkatan mutu hubungan dengan wisatawan.

\section{Tipologi Wisatawan yang Berkunjung ke Pura Tirta Empul}

Studi ini mendiskusikan tipologi wisatawan dengan menggunakan konsep Tipologi Wisatawan Budaya yang dikemukakan oleh McKercher dan Du Cros (2002) dengan lima kelompok wisatawan. Adapun kelompok dan persentase jumlah wisatawan yang berkunjung ke Pura Tirta Empul dapat dilihat pada Tabel 3.

Tabel 3. Tipologi Wisatawan Budaya

\begin{tabular}{|l|l|c|c|}
\hline No & \multicolumn{1}{|c|}{ Kelompok } & Jumlah (Org) & Total (\%) \\
\hline 1. & Sightseeing tourist & 41 & $41 \%$ \\
\hline 2. & Purposeful tourist & 36 & $36 \%$ \\
\hline 3. & Casual tourist & 14 & $14 \%$ \\
\hline 4. & Serendipitous tourist & 7 & $7 \%$ \\
\hline 5. & Incidental tourist & 2 & $2 \%$ \\
\hline \multicolumn{2}{|l|}{ Total Jumlah } & 100 & $100 \%$ \\
\hline
\end{tabular}

Sumber: Hasil Penelitian (2018)

\section{Sightseeing Tourist}

Berdasarkan Tabel 3, banyaknya wisatawan yang berkunjung ke Pura Tirta Empul dengan karakteristik sightseeing tourist yakni 41\%. Jumlah besar dari kelompok sightseeing tourist menunjukkan bahwa mayoritas wisatawan yang berkunjung ke Pura Tirta Empul memiliki motivasi budaya yang kuat, turut dalam aktivitas yang ada di Pura Tirta Empul, dan kecenderungan lain yaitu wisatawan masih mempunyai anggapan Pura Tirta Empul adalah tempat rekreasi, yang kemudian menjadikan orientasi mereka semata-mata tidak hanya untuk pencarian budaya, tetapi untuk bersenang-senang, sehingga pengalaman yang mereka 
dapatkan khususnya dari aktivitas-aktivitas yang terkait dengan agama dan budaya tidak mendalam. Pemahaman dan pemaknaan atas simbol-simbol tidak mampu dipahami secara baik yang dikarenakan minimnya pengetahuan wisatawan atau dalam perspektif lain juga dikarenakan terbatasnya kemampuan pengelola dalam memberikan informasi, atau menarasikan komponen Pura Tirta Empul sebagai kebudayaan maupun daya tarik wisata.

\section{Purposeful Tourist}

Diurutan kedua yaitu kelompok purposeful tourist dengan persentase 36\%. Hal ini menunjukkan bahwa banyak juga wisatawan yang memiliki motivasi budaya sebagai latar belakang kunjungan dan terlibat dalam berbagai aktivitas di Pura Tirta Empul. Ciri lain wisatawan dengan kelompok purposeful tourist adalah pengalaman yang didapat. Berbeda dengan kelompok sightseeing tourist, kelompok purposeful tourist memperoleh pengalaman yang dalam atas aktivitas yang dilakukan. Salah satu reasoning-nya yaitu wisatawan telah mempelajari Pura Tirta Empul, baik melalui internet, maupun arahan pemandu wisata yang datang bersama mereka, sehingga informasi mengenai Pura Tirta Empul telah dipahami sebelum mereka berkunjung.

\section{Casual Tourist}

Urutan ketiga jumlah wisatawan yang berkunjung ke Pura Tirta Empul adalah kelompok casual tourist sebesar 14\%. Ini membuktikan bahwa terdapat juga wisatawan yang berkunjung ke Pura Tirta Empul yang hanya sekedar untuk berekreasi, melihat-lihat atau sekedar menghabiskan waktu di suatu daya tarik wisata yang umumnya baru. Hal ini menjadi logis karena di Pura Tirta Empul wisatawan tidak hanya terlibat dalam aktivitas-aktivitas yang bernuansa agama dan budaya, tetapi adanya panorama alam dan ekologi Pura Tirta Empul secara umum dapat dikatakan sangat baik khususnya bagi wisatawan pecinta alam dan pencari ketenangan. 


\section{Serendipitous Tourist}

Urutan selanjutnya wisatawan yang berkunjung ke Pura Tirta Empul adalah kelompok serendipitous tourist dengan persentase sebesar 7\%. Ini menunjukkan bahwa Pura Tirta Empul juga dikunjungi oleh wisatawan yang motif utama kunjungannya bukanlah difokuskan untuk hal-hal yang terkait dengan budaya, tetapi aktivitas budaya yang tersaji di Pura Tirta Empul mampu dirasakan dan dimaknai secara baik oleh wisatawan sehingga pada akhirnya kunjungan tersebut sangat bermakna dan wisatawan memperoleh. Salah satu faktornya adalah wisatawan yang melakukan perjalanan wisata dengan menggunakan agen perjalanan yang perencanaannya sudah dirancang.

\section{Incidental Tourist}

Urutan terakhir dari kelompok wisatawan yang berkunjung ke Pura Tirta Empul adalah kelompok incidental tourist dengan jumlah persentase sebesar 2\%. Hasil ini membuktikan bahwa adanya wisatawan yang datang secara kebetulan tanpa adanya perencanaan yang matang ataupun dilatarbelakangi dengan motif budaya.

\section{Perilaku Wisatawan yang Berkunjung ke Pura Tirta Empul}

\section{Aktivitas Wisatawan}

Sebagaimana esensi dari pariwisata yaitu pergerakan, maka adanya wisatawan di suatu daya tarik wisata pasti disertai dengan aktivitas-aktivitas yang dilakukan di daya tarik wisata tersebut. Berdasarkan hasil analisis, aktivitasaktivitas yang dilakukan wisatawan khususnya wisatawan mancanegara yang berkunjung ke Pura Tirta Empul adalah aktivitas rekreasi dan aktivitas yang terkait dengan keagamaan.

Aktivitas rekreasi wisatawan yang ada di Pura Tirta Empul meliputi berjalanjalan mengelilingi areal Pura, berfoto-foto, dan memberi makan ikan. Berikut adalah foto-foto yang diambil pada saat penelitian dilakukan:

325 JUMPA Volume 05, Nomor 02, Januari 2019 


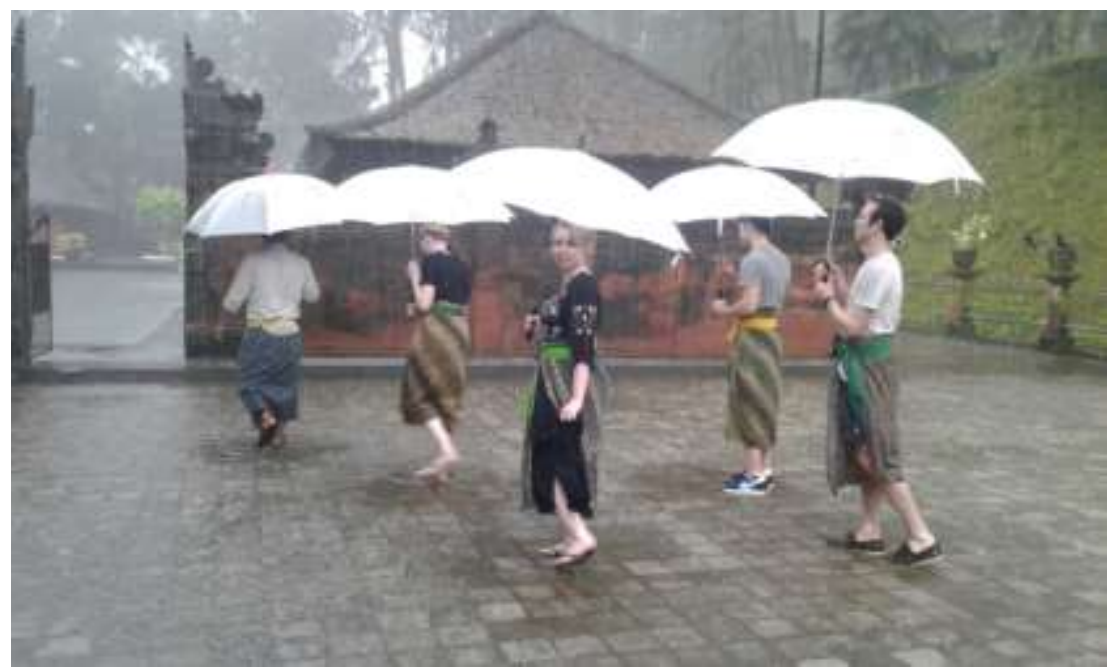

Gambar 1. Wisatawan yang sedang berkeliling di Area Pura Tirta Empul Sumber : Peneliti (2018)

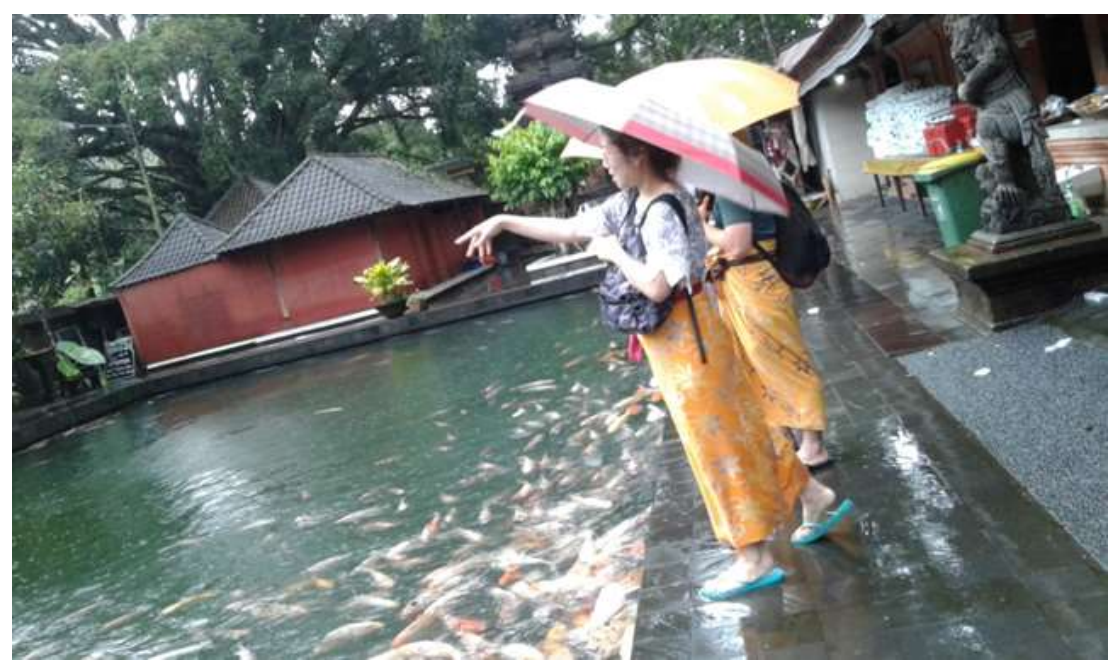

Gambar 2. Wisatawan yang sedang memberi makan ikan di kolam ikan Pura Tirta Empul.

Sumber : Peneliti (2018)

Pura Tirta Empul sebagai daya tarik wisata tidak hanya menyuguhkan aktivitas rekreasi bagi pengunjungnya. Sebagai daya tarik wisata budaya, produk Pura Tirta Empul menyajikan tontonan tradisi dan budaya masyarakat Bali. Secara sederhana, kegiatan-kegiatan keagamaan dan hal lainnya yang kental hubungannya dengan nilai budaya telah menjadi faktor penarik wisatawan. Wisatawan yang berkunjung ke Pura Tirta Empul melakukan berbagai aktivitas yang terkait dengan 
keagamaan seperti pemujaan dan penyucian diri (panglukatan). Berikut foto-foto wisatawan yang melakukan kegiatan persembahyangan dan penyucian diri.

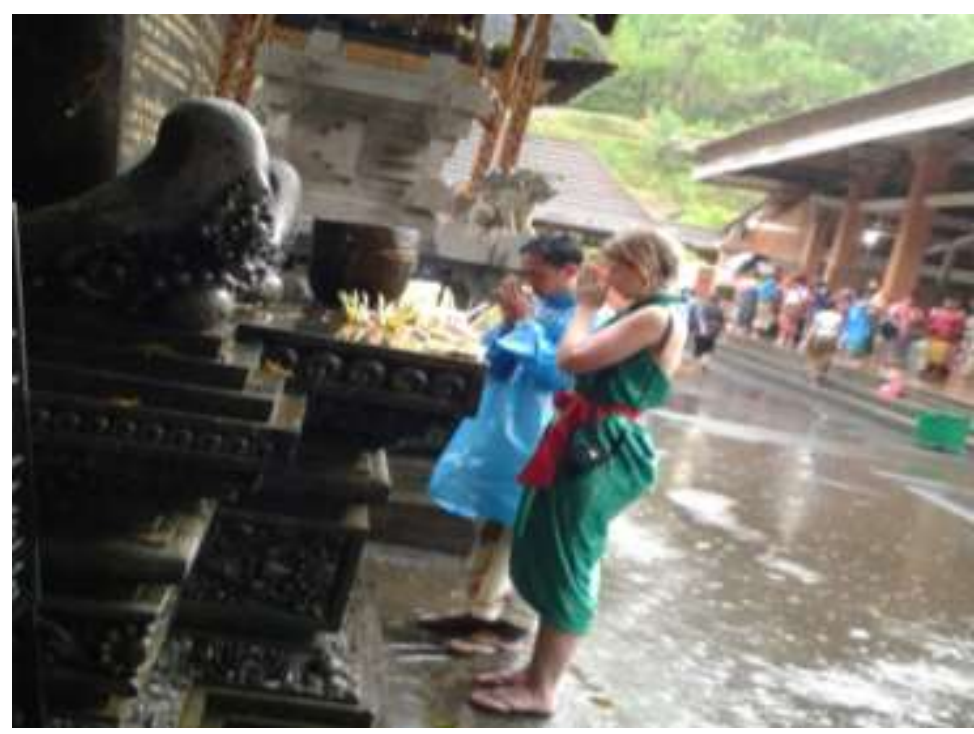

Gambar 3. Wisatawan melakukan pemujaan yang didampingi seorang guide.

Sumber : Peneliti (2018)

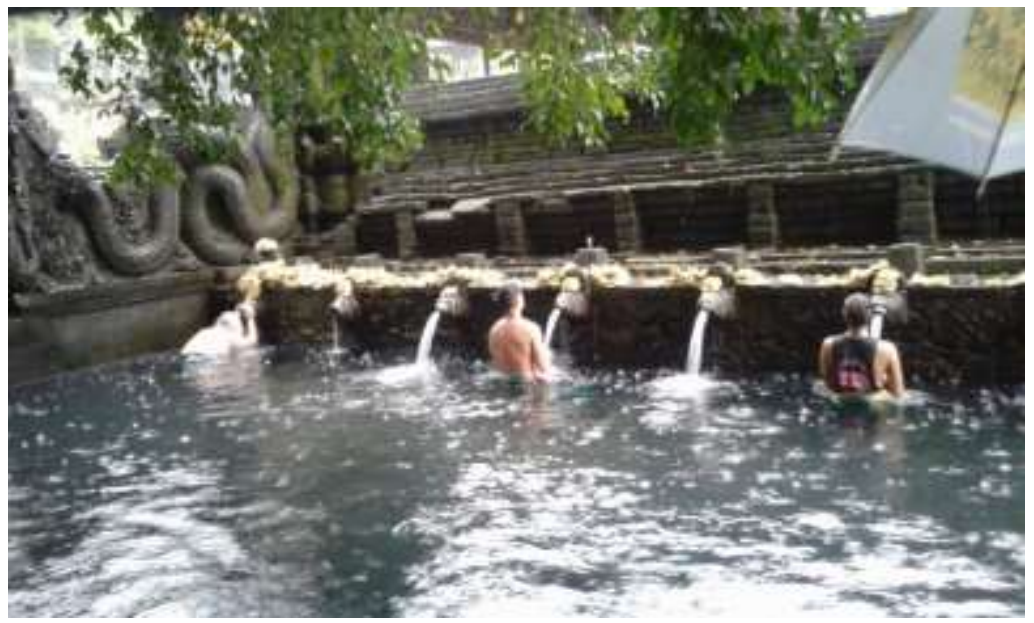

Gambar 4. Wisatawan melakukan penyucian diri di kolam Pura Tirta Empul

Sumber : Peneliti (2018)

\section{Pengeluaran}

Jumlah persentase tertinggi pengeluaran wisatawan selama berada di Pura Tirta Empul adalah sebesar 5 - 10 USD. Ini berarti tidak begitu banyak pengeluaran wisatawan pada saat berkunjung ke Pura Tirta Empul. Hal ini juga disebabkan 
karena harga-harga keperluan untuk pemujaan atau sarana rekreasi lainnya seperti makanan ikan yang cukup terjangkau harganya sehingga membuat wisatawan tidak perlu mengeluarkan banyak uang.

\section{Niat untuk Berkunjung Kembali}

Hasil studi menunjukkan sebesar $66 \%$ wisatawan tidak memiliki niat untuk berkunjung kembali ke Pura Tirta Empul. Dengan kata lain mayoritas wisatawan merasa cukup hanya berkunjung sekali ke Pura Tirta Empul.

\section{Simpulan dan Saran}

Berdasarkan hasil analisis, motivasi wisatawan yang berkunjung ke Pura Tirta Empul dapat ditinjau dari dua faktor. Pertama, jika ditinjau dari faktor penariknya, motivasi utama wisatawan yang berkunjung ke Pura Tirta Empul adalah motivasi daya tarik wisata alam dan budaya dengan skor 4, 65 dengan penilaian sangat setuju. Sedangkan jika dilihat dari faktor pendorongnya, motivasi utama wisatawan berkunjung ke Pura Tirta Empul adalah untuk bersantai dan berelaksasi dengan skor 4, 40 dengan penilaian sangat baik. Tipologi wisatawan budaya yang berkunjung ke Pura Tirta Empul sebagian besar adalah sightseeing tourist. Jika dilihat dari akitivitas yang dilakukan, wisatawan di Pura Tirta Empul melakukan kegiatan rekreasi dan kegiatan yang terkait dengan keagamaan. Mayoritas wisatawan tidak ingin berkunjung kembali ke Pura Tirta Empul dikarenakan motivasi mereka datang ke Pura Tirta Empul adalah untuk mengetahui dan mempelajari budaya akan tetapi pengalaman yang mereka peroleh tidak mendalam.

Penelitian ini hanya mengkaji aspek-aspek wisatawan yang menyangkut motivasi, tipologi, dan perilaku wisatawan. Apabila ada peneliti lain yang tertarik melakukan penelitian di Pura Tirta Empul, beberapa aspek yang belum diteliti seperti persepsi wisatawan terhadap kualitas layanan yang ada di Pura Tirta Empul yang juga merupakan bagian dari perilaku wisatawan maupun aspek-aspek lain 
I Nyoman Agus Wira Prabawa, I Nyoman Sunarta, I Gusti Ayu Oka Suryawardani

yang belum tersentuh dalam penelitian ini adalah memungkinkan untuk diadakan penelitian lebih lanjut.

\section{Daftar Pustaka}

Palimbunga, Ika Pujiningrum. 2018. Jurnal Magister Pariwisata (JUMPA). Vol. 05, No. 01, pp.193-210. ISSN 2502-8022.

Pitana, I. G. dan Gayatri, P. 2005. Sosiology Pariwisata. Yogyakarta: Andi

Setiawan, I Ketut. 2011. “Komodifikasi Pura Tirta Empul dalam Konteks Pariwisata Global” (Disertasi). Denpasar: Universitas Udayana.

Suteja, I Wayan., Ardika, I Wayan., Pujaastawa, Ida Bagus Gde. 2018. Jurnal Magister Pariwisata (JUMPA). Vol. 05, No. 01, pp. 111-128. ISSN 2502-8022.

Woodside, Arch G. dan Drew Martin. 2008. Tourism Management

Zeng, Guojun. 2015. Tourism and Hospitality Development between China and EU. Guangzhou: Springer.

\section{Profil Penulis}

I Nyoman Agus Wira Prabawa, SS., M. Par adalah alumni mahasiswa Fakultas Pariwisata, Universitas Udayana. Ia menyelesaikan Program Sarjana pada Fakultas Sastra Universitas Udayana tahun 2014 dan Magister Pariwisata Universitas Udayana tahun 2018.

Dr. Drs. I Nyoman Sunarta adalah Dekan Fakultas Pariwisata Universitas Udayana periode 2018-2022. Beliau menyelesaikan pendidikan sarjana di UGM, Program Magister Ilmu Lingkungan di UGM, dan Program Doktor di Universitas Udayana.

Dr. Ir. I Gusti Ayu Oka Suryawardani, M. Mgt., Ph. D. adalah Koordinator Program Studi Magister Pariwisata periode 2018-2022. Ia meraih Double Degree Indonesia Perancis (DDIP): UNUD-Paris 1 Pantheon Sorbonne, Paris, France. 